\title{
NIFEDIPINE LOWERS COCAINE-INDUCED BRAIN AND LIVER ENZYME ACTIVITY AND COCAINE URINARY EXCRETION IN RATS
}

\author{
Vessela VITCHEVA ${ }^{1}$, Rumyana SIMEONOVA ${ }^{1}$, Dima KAROVA², and Mitka MITCHEVA ${ }^{1}$ \\ Department of Pharmacology, Pharmacotherapy and Toxicology, Faculty of Pharmacy, Medical University Sofial, \\ Doping Control Laboratory, State Agency for Youth and Sport ${ }^{2}$, Sofia, Bulgaria
}

Received in October 2010

CrossChecked in February 2011

Accepted in March 2011

\begin{abstract}
The aim of this study was to see how nifedipine counters the effects of cocaine on hepatic and brain enzymatic activity in rats and whether it affects urinary excretion of cocaine. Male Wistar rats were divided in four groups of six: control, nifedipine group ( $5 \mathrm{mg} \mathrm{kg}^{-1}$ i.p. a day for five days); cocaine group (15 mg $\mathrm{kg}^{-1}$ i.p. a day for five days), and the nifedipine+cocaine group. Twenty-four hours after the last administration, we measured neuronal nitric oxide synthase (nNOS) activity in the brain and cytochrome P450 quantity, ethylmorphine-N-demethylase, and anilinehydroxylase activity in the liver. Urine samples were collected $24 \mathrm{~h}$ after the last cocaine and cocaine+nifedipine administration. Urinary cocaine concentration was determined using the GC/MS method.

Cocaine administration increased brain nNOS activity by $55 \%(\mathrm{p}<0.05)$ in respect to control, which indicates the development of tolerance and dependence. In the combination group, nifedipine decreased the nNOS activity in respect to the cocaine-only group.

In the liver, cocaine significantly decreased and nifedipine significantly increased cytochrome P450, ethylmorphine-N-demethylase, and anilinehydroxylase in respect to control. In combination, nifedipine successfully countered cocaine effects on these enzymes.

Urine cocaine excretion in the cocaine+nifedipine group significantly dropped (by $35 \%$ ) compared to the cocaine-only group.

Our results have confirmed the effects of nifedipine against cocaine tolerance and development of dependence, most likely due to metabolic interactions between them.
\end{abstract}

KEY WORDS: anilinehydroxylase, cytochrome P450, ethylmorphine-N-demethylase, GSH, $n N O S$

Multiple cocaine administration leads to behavioural activation, tolerance, and development of dependence in animals and humans (2). These adaptive changes in the central nervous system (CNS) are largely mediated by L-type calcium channels (3). One of the mechanisms underlying drug tolerance and dependence, and the related withdrawal syndrome, is a change in calcium homeostasis and the consequent activation of N-methyl-D-aspartate/nitric oxide (NMDA/NO) cascade (4). Changes in $\mathrm{Ca}^{2+}$ homeostasis seem to be induced by calcium channel blockers of the 1,4-dihydropyridine type.

In our earlier studies (5-6), we have demonstrated that nifedipine, co-administered with morphine, attenuates withdrawal symptoms, which correlate with changes in the activity of neuronal nitric oxide synthase (nNOS) (5). Interactions between morphine and nifedipine in the liver and on the level of urine excretion were also observed, probably due to a metabolic interaction between these compounds (6). 
Nifedipine is known to induce one of the most abundant cytochrome $\mathrm{P} 450$ isoform CYP $3 \mathrm{~A}$ and other isoenzymes, including CYP 2B (7). In rats, these two enzymes mediate partial N-demethylation of cocaine to norcocaine (8). Data on cocaine effects on drugmetabolising enzymes are controversial (9-11). In our earlier studies, we investigated the effect of cocaine on brain and liver cytochrome P450 after multiple administration in rats and found that the cumulative intraperitoneal (i.p.) dose of $15 \mathrm{mg} \mathrm{kg}^{-1}$ led to a significant increase in the quantity of cytochrome $\mathrm{P} 450$ (12) and in ethylmorphine-N-demethylase (CYP 3A) (13) and anilinehydroxylase (CYP 2E1) activity (14). These findings suggest that cocaine and nifedipine interact in the brain and liver. The aim of this study was to see to which extent and also to see if nifedipine affects urinary excretion of cocaine in Wistar rats.

\section{MATERIAL AND METHODS}

\section{Animals}

To avoid the influence of hormonal fluctuations during the oestrus cycle, this study included only male Wistar rats (b. w. $200 \mathrm{~g}$ to $230 \mathrm{~g}$ ). Many have observed sex-related differences in the behavioural response to and toxicity of cocaine $(15,16)$.

The animals were housed in plexiglass cages (three per cage ) at $(20 \pm 2){ }^{\circ} \mathrm{C}$ and $12 \mathrm{~h}$ light/dark cycles. Food and tap water were provided ad libitum. The animals were purchased from the National Breeding Centre, Slivnitza, Bulgaria. All experiments were performed after at least one week of adaptation to this environment. All procedures were approved by the Institutional Animal Care Committee and observed the principles of the European Convention for the Protection of Vertebrate Animals used for Experimental and Other Scientific Purposes (ETS 123) (17).

\section{Experimental design}

The animals were randomised into four groups of six. The first group received i.p. doses of $5 \mathrm{mg} \mathrm{kg}^{-1}$ nifedipine once daily for five days (18). The second group received $15 \mathrm{mg} \mathrm{kg}^{-1}$ of cocaine i.p. once daily for five days (19). The third group received nifedipine $\left(5 \mathrm{mg} \mathrm{kg}^{-1}\right)$ followed by cocaine $\left(15 \mathrm{mg} \mathrm{kg}^{-1}\right) 30 \mathrm{~min}$ later. This combination was also administered once daily for five days. The selection of nifedipine and cocaine doses was based on our earlier study (12) and on doses commonly used by other laboratories (18, 19). Our earlier study (12) demonstrated that $5 \mathrm{mg} \mathrm{kg}^{-}$ ${ }^{1}$ of nifedipine, administered intraperitoneally to male Wistar rats once daily for five days, led to increases in cytochrome P450. The fourth group consisted of control animals, which were treated with saline, involved in the experiment from the very beginning, and housed under the same standard laboratory conditions as the treated animals.

Twenty-four hour urine was collected from animals from the second and third group, which were transferred to stainless steel metabolism cages $40 \mathrm{~min}$ after the last injection of cocaine and/or nifedipine.

Twenty-four hours after the last injection, all animals were killed by decapitation, brain and liver removed, washed with ice-cold saline $(0.9 \% \mathrm{NaCl})$, blotted dry, weighed, and stored on ice. Liver was then divided into three pieces of one gram each to determine cytochrome P450, glutathione (GSH), and enzyme activity.

\section{Chemicals and reagents}

All reagents used were of analytical grade. Cocaine hydrochloride, nifedipine hydrochloride, sucrose, Tris, DL-dithiotreitol, phenylmethylsulfonyl fluoride, potassium phosphate, calcium chloratum $\left(\mathrm{CaCl}_{2}\right)$, magnesium chloratum $\left(\mathrm{MgCl}_{2}\right)$, L-arginine, L-valine, haemoglobin bovine, beta-Nicotinamide adenine dinucleotide 2'-phosphate reduced tetrasodium salt (beta-NADPH), ethylenediaminetetraacetic acid (EDTA), and bovine serum albumin (fraction V) were purchased from Sigma Chemical Co. (Taufkirchen, Germany). 2,2'-dinitro-5,5'dithiodibenzoic acid (DTNB) was obtained from Merck (Darmstadt, Germany).

\section{Preparation of brain tissue extracts and assessment of nNOS activity}

Rats were decapitated and the brains minced and homogenised in $9 \mathrm{~mL}$ of a buffer containing $320 \mathrm{mmol} \mathrm{L}^{-1}$ sucrose, $50 \mathrm{mmol} \mathrm{L}^{-1}$ Tris, $1 \mathrm{mmol} \mathrm{L}^{-1}$ DL-dithiotreitol, $100 \mu \mathrm{g} \mathrm{L}^{-1}$ phenylmethylsulfonyl fluoride ( $\mathrm{pH}=7.2$ ), according to the method used by Knowels and Moncada (20). The homogenates were then centrifuged at 17,000 rpm for $60 \mathrm{~min}$. Protein content was measured using the method of Lowry (21) with bovine serum albumin as a standard.

nNOS activity was measured spectrophotometrically, using the oxidation of oxyhaemoglobin to methaemoglobin by $\mathrm{NO}(20)$ with slight modifications. 
The incubation medium contained $40 \mathrm{mmol} \mathrm{L}^{-1}$ potassium phosphate buffer, $\mathrm{pH}=7.2,200 \mu \mathrm{mol} \mathrm{L}^{-1}$ $\mathrm{CaCl}_{2}, 1 \mathrm{mmol} \mathrm{L}^{-1} \mathrm{MgCl}_{2}, 100 \mu \mathrm{mol} \mathrm{L}^{-1} \mathrm{~L}$-arginine, $50 \mathrm{mmol} \mathrm{L}^{-1} \mathrm{~L}$-valine, $2.6 \mu \mathrm{mol} \mathrm{L}-1$ oxyhaemoglobin, $100 \mu \mathrm{mol} \mathrm{L}^{-1} \mathrm{NADPH}$, and brain extract. The concentration of oxyhaemoglobin in the original method of Knowels (20) was $1.6 \mu \mathrm{mol} \mathrm{L}^{-1}$, but we adjusted it to $2.6 \mu \mathrm{mol} \mathrm{L^{-1 }}$ to optimise reproducibility and to obtain spectra with a higher amplitude.

Change in absorbance at $401 \mathrm{~nm}$ and $421 \mathrm{~nm}$ was monitored with a double split beam spectrophotometer (Spectro UV-VIS Split) at $37^{\circ} \mathrm{C}$. Enzyme activity was expressed in nmol mg-1 per minute, using a millimolar extinction coefficient for methaemoglobin $77.2 \mathrm{~L} \mathrm{~mol}^{-1} \mathrm{~cm}^{-1}$.

\section{Urine analysis}

For urine collection, animals were housed for $24 \mathrm{~h}$ in metabolism cages, equipped to separate urine and faeces. Food and water were available ad libitum.

A $1.0-\mathrm{mL}$ aliquot of urine was mixed with $\mathrm{NaHCO}_{3}: \mathrm{K}_{2} \mathrm{CO}_{3}(1: 2), \mathrm{pH}=9.6$ by shaking manually in $20 \mathrm{~mL}$ glass tubes. Then we added $\mathrm{Na}_{2} \mathrm{SO}_{4}$ anhydrous and $20 \mu \mathrm{L}$ codeine as internal standard. Samples were extracted with $4 \mathrm{~mL}$ of tertbutylmethylether for $30 \mathrm{~min}$ and then centrifuged at $2,500 \mathrm{rpm}$ for $5 \mathrm{~min}$. To separate the organic from non-organic phase, the samples were put in cryostat at $-29^{\circ} \mathrm{C}$. The separated ether phase was then evaporated to dryness under a stream of nitrogen.

The purified dried extract was added to $50 \mu \mathrm{L} \mathrm{N}$ Methyl-N-trimethylsilyltrifluoroacetamide (MBTFA) and derivatised at $80{ }^{\circ} \mathrm{C}$ for $20 \mathrm{~min}$. Aliquots of $1 \mu \mathrm{L}$ were injected into a gas chromatograph/mass spectrometer (GC-MS, Agilent Technology, Santa Clara, USA) to determine cocaine concentrations.

\section{Preparations of standard and internal control}

Stock solution of cocaine was prepared in methanol to yield a final drug concentration of $10 \mu \mathrm{g} \mathrm{L}^{-1}$. The standard curve for cocaine was linear over the concentration range of $0.1 \mu \mathrm{g} \mathrm{L}^{-1}$ to $0.4 \mu \mathrm{g} \mathrm{L}^{-1}$. Linearity was verified by adding $(10,20,30$, and 40) $\mu \mathrm{L}$ from the stock solution to drug-free urine. The concentration of the working solution of the internal standard, codeine, was $21.8 \mu \mathrm{g} \mathrm{L}^{-1}$.

\section{Preparation of liver microsomes for biochemical assay}

The excised liver was perfused with $0.15 \mathrm{~mol} \mathrm{~L}^{-1}$ $\mathrm{KCl}$, minced, and homogenised with $3 \mathrm{~mL}$ of $1.17 \%$
$\mathrm{KCl}$ solution in a glass homogenizer (PX-OX 2000) as described by Guengerich (22). Liver homogenates were then centrifuged at 9,000 rpm for $30 \mathrm{~min}$. Supernatant fractions were further centrifuged at $38,000 \mathrm{rpm}$ for $60 \mathrm{~min}$. The resulting microsomal pellets were stored at $-20{ }^{\circ} \mathrm{C}$ until assayed.

Ethylmorphine-N-demethylase activity was evaluated based on the measurement of formaldehyde, trapped in the solution as semicarbazone, using the colorimetric procedure of Nash (23), at $415 \mathrm{~nm}$.

Aniline hydroxylase activity was evaluated colorimetrically, based on the measurement at $630 \mathrm{~nm}$ of a phenol-indophenol complex, which is a converted form of 4-aminophenol (24).

To quantify cytochrome $\mathrm{P} 450$ we resuspended the microsomal pellets and diluted them in phosphate buffer $+1 \mathrm{mmol} \mathrm{L}^{-1} \mathrm{EDTA}(\mathrm{pH}=7.4)(25)$. The protein content of liver homogenate was measured using the method of Lowry (17) with bovine serum albumin as a standard. Cytochrome P450 quantity was quantified spectrophotometrically as a complex with $\mathrm{CO}$ at $450 \mathrm{~nm}$ and expressed as nmol $\mathrm{mg}^{-1}$.

To assess GSH levels, samples of liver tissue were homogenised in $5 \%$ trichloracetic acid (TCA) and centrifuged at 4,000 rpm for 20 minutes. GSH was assessed by measuring non-protein sulfhydryls after precipitation of proteins with TCA, followed by measurement of thiols in the supernatant by the DTNB reagent using the method described by Bump et al. (26).

\section{Statistical analysis}

Statistical analysis included ANOVA and Student's $t$-test. Probability values of less than 0.05 were considered significant. The results were presented as means \pm SD of six animals per group. For each parameter three parallel samples were tested.

\section{RESULTS}

Table 1 shows the effects of cocaine and nifedipine on nNOS activity in rat brain. Compared to control, cocaine administered alone increased nNOS activity by $55 \%(\mathrm{p}<0.05)$ while nifedipine alone did not significantly change its activity. In combination with cocaine, however, nifedipine decreased nNOS activity by $27 \%(\mathrm{p}<0.05)$ in respect to cocaine alone.

Table 2 shows the effects of cocaine and nifedipine, administered alone and in combination, on liver 
enzymes and P450. Nifedipine given alone showed the opposite effects to cocaine, significantly increasing cytochrome P450 quantity (28\%) and ethylmorphineN-demethylase (34\%) and anilinehydroxylase (27\%) activity in respect to control. These results are in good correlation with our earlier findings $(5,12)$.

Cocaine significantly depleted GSH (by $29 \%$; $\mathrm{p}<0.05$ in respect to control), while nifedipine did not change its levels. However, in the cocaine+nifedipine group GSH level increased $20 \%$ in respect to the cocaine-only group $(\mathrm{p}<0.05)$.

In combination, nifedipine significantly increased cytochrome P450 (by $34 \%$ ), ethylmorphine-Ndemethylase (101\%) and anilinehydroxylase (41\%) activities, and increases GSH levels (20\%) in relation to the cocaine only group. Compared to control, GSH levels dropped $15 \%(\mathrm{p}<0.05)$.

Table 3 shows the effects of nifedipine on urinary excretion of cocaine. In the nifedipine+cocaine group, cocaine excretion dropped $35 \%(\mathrm{p}<0.05)$ in comparison with the cocaine-only group.

\section{DISCUSSION}

The significant increase in nNOS activity observed after five days of cocaine administration in our study confirms earlier findings $(19,27)$ and could be regarded as a sign of tolerance and development of dependence.

Table 1 nNOS activity in rat brain after multiple administration of cocaine (15 $\mathrm{mg} \mathrm{kg}^{-1}$ per day) and nifedipine (5 $\mathrm{mg} \mathrm{kg}^{-1} \mathrm{per}$ day), alone and in combination

\begin{tabular}{|c|c|c|c|}
\hline Group & $\begin{array}{c}\text { nNOS activity / nmol } \mathrm{min}^{-1} \\
\mathrm{mg}^{-1} \text { of tissue }\end{array}$ & Effect $v$ s. control / \% & Effect $v$ s. cocaine / \% \\
\hline Control & $0.604 \pm 0.04$ & 100 & \\
\hline Nifedipine & $0.597 \pm 0.08$ & 98.9 & \\
\hline Cocaine & $0.935 \pm 0.012 *$ & 155 & 100 \\
\hline Nifedipine + Cocaine & $0.683 \pm 0.10^{+}$ & 113 & 73 \\
\hline
\end{tabular}

Note: Data are expressed as mean $\pm S D$ of six animals

$* p<0.05$ vs. control group

$p<0.05$ vs. cocaine treated group

Table 2 Multiple administration of cocaine (15 $\mathrm{mg} \mathrm{kg}^{-1}$ per day), alone and along with nifedipine (5 $\mathrm{mg} \mathrm{kg}^{-1} \mathrm{per}$ day) - effect on liver biochemical parameters

\begin{tabular}{|c|c|c|c|c|}
\hline Group & $\begin{array}{c}\text { Cytochrome } \\
\text { P450 }^{\#} / \text { nmol mg }^{-1}\end{array}$ & $\begin{array}{c}\text { Ethylmorphine- } \\
\mathrm{N} \text {-demethylase activity } \\
\text { as } \mathrm{HCHO} / \mathrm{nmol} \mathrm{min}^{-1} \mathrm{mg}^{-1} \\
\text { of tissue }\end{array}$ & $\begin{array}{l}\text { Anilinehydroxylase } \\
\text { activity / nmol min } \\
\text { mg } \\
\text { mg }^{-1} \text { of tissue }\end{array}$ & $\begin{array}{c}\text { Quantity of GSH / } \\
\text { nmol g } \mathbf{g}^{-1}\end{array}$ \\
\hline Control & $0.345 \pm 0.02$ & $0.258 \pm 0.02$ & $0.037 \pm 0.002$ & $5.31 \pm 0.20$ \\
\hline Nifedipine & $0.440 \pm 0.04 *$ & $0.346 \pm 0.02 *$ & $0.047 \pm 0.003 *$ & $5.18 \pm 0.13$ \\
\hline Cocaine & $0.286 \pm 0.01 *$ & $0.165 \pm 0.04 *$ & $0.031 \pm 0.003 *$ & $3.77 \pm 0.11^{*}$ \\
\hline $\begin{array}{l}\text { Cocaine }+ \\
\text { Nifedipine }\end{array}$ & $0.384 \pm 0.05^{+}$ & $0.332 \pm 0.01^{*+}$ & $0.044 \pm 0.005^{*+}$ & $4.54 \pm 0.41^{*+}$ \\
\hline
\end{tabular}

Note: Data are expressed as mean $\pm S D$ of six animals

$* p<0.05 v$ s. control group

$+p<0.05$ vs. cocaine treated group

\#- previously published in (12)

Table 3 Urinary excretion of cocaine $\left(15 \mathrm{mg} \mathrm{kg}^{-1}\right.$ per day) after multiple administrations alone and in combination with nifedipine (5 $\mathrm{mg} \mathrm{kg}^{-1}$ per day)

\begin{tabular}{lccc}
\hline Group & $\begin{array}{c}\text { Urinary concentration of } \\
\text { cocaine } / \boldsymbol{\mu g} \mathbf{~ m L}^{-1}\end{array}$ & $\begin{array}{c}\text { 24-h urinary } \\
\text { volume } / \mathbf{~ m L}\end{array}$ & $\begin{array}{c}\text { Effect } \boldsymbol{v s .} \\
\text { cocaine } / \boldsymbol{\%}\end{array}$ \\
\hline Cocaine & $0.57 \pm 0.02$ & $6 \pm 1$ & - \\
Cocaine + Nifedipine & $0.37 \pm 0.09^{*}$ & $6.5 \pm 1.5$ & $\downarrow 35$ \\
\hline
\end{tabular}

Note: data are expressed as mean $\pm S D$ of six animals

$* p<0.05$ vs. cocaine treated group 
Vetulani (28) has proposed that L-type $\mathrm{Ca}^{2+}$ channel blockers like 1,4-dihydropiridines could be used as anti-addiction agents. Our results showed that nifedipine countered cocaine effects on nNOS activity when given in combination with it. This is in agreement with a study by Nasif et al. (29), who found that repeated cocaine administration stimulated voltagesensitive $\mathrm{Ca}^{2+}$ channel function in rat $\mathrm{mPFC}$ pyramidal neurons as a result of the increased activity of L-type $\mathrm{Ca}^{2+}$ channels. The authors also showed that selective blocking of L-type $\mathrm{Ca}^{2+}$ channels by nifedipine not only significantly increased the threshold but also reduced the duration and amplitude of $\mathrm{Ca}^{2+}$ plateau potentials that resulted in a decrease of $\mathrm{Ca}^{2+}$ influx into the neurons.

Apart from this interaction on the level of the CNS, cocaine and nifedipine are also expected to interact in the liver, since both undergo hepatic biotransformation. Nifedipine is a substrate of CYP $3 \mathrm{~A}$ and other isoenzymes such as CYP 2B $(30,31)$ which mediate cocaine's N-demethylation to N-hydroxynorcocaine in liver microsomes (32-34). Our results seem to confirm this interaction, since nifedipine successfully counteracted cocaine effects when administered in combination.

This includes lowering cocaine-induced toxic effects in the liver. According to Yu et al. (35), cocaine is oxidised by cytochrome $\mathrm{P} 450$ to $\mathrm{N}$-hydroxynorcocaine and norcocaine nitroxyde. The latter is a free radical that induces lipid peroxidation and GSH depletion. In our study, we detected a significant decrease in GSH levels after cocaine administration. Co-administration with nifedipine, however, resulted in increased GSH levels (Table 2). Similarly, Mazumder et al. (36) suggested that nifedipine attenuated lipid peroxidation and glutathione depletion caused by sulphur mustard.

In order to confirm this metabolic interaction, we also investigated the effects of nifedipine on the urinary excretion of cocaine. In a study by Nayak et al. (38), urinary excretion of unchanged cocaine in chronically treated rats was around $1.5 \%$ (37). In our study, we measured unchanged urinary cocaine because we expected it to increase due to nifedipine interference with its cytochrome P450-mediated metabolism. However, our results proved us wrong, as urinary cocaine excretion in the combination group was significantly lower than in the cocaine-only group (Table 3). These findings suggest that the observed metabolic interaction between cocaine and nifedipine might result in an increased activity of non-microsomal enzymes, which may explain the decreased urinary excretion of unchanged cocaine.

\section{REFERENCES}

1. Filip M, Frankowska M, Zaniewska M, Golda A, Przegalinski E. The serotonergic system and its role in cocaine addiction. Pharmacol Rep 2005;57:685-700.

2. Mello NK, Mendelson JH. Cocaine, hormones and behavior: clinical and preclinical studies. In: Pfaff DW, Arnold AP, Etgen AM, Fahrbach SE, Rubin RT, editors. Hormones, brain and behavior. New York: Academic Press; 2002. p. 665745 .

3. Vetulani J. Wapń i kanały wapniowe regulowane potencjałem [Calcium and voltage-dependent calcium channels, in Polish]. Kosmos 1997;46:491-505.

4. Pasternak GW, Kolesnikov YA, Babey AM. Perspectives on the N-methyl-D-aspartate/nitric oxide (NMDA/NO) cascade and opioid tolerance. Neuropsychopharmacology 1995;13:309-13.

5. Vitcheva V, Mitcheva M. Effects of nifedipine on behavioral and biochemical parameters in rats after multiple morphine administration. Methods Find Exp Clin Pharmacol 2004;26:631-4.

6. Vitcheva V, Karova D, Mitcheva M. Influence of nifedipine on morphine elimination after multiple administration in rats. In: Tonev S, Kanev K, Dishovsky C, editors. Medical management of chemical and biological casualties. Sofia: Publishing house IRITA; 2009. p. 274-80.

7. Drocourt L, Pascussi JM, Assenat E, Fabre JM, Maurel P, Vilarem MJ. Calcium channel modulators of the dihydropyridine family are human pregnane $\mathrm{X}$ receptor activators and inducers of CYP $3 \mathrm{~A}, \mathrm{CYP} 2 \mathrm{~B}$ and CYP $2 \mathrm{C}$ in human hepatocytes. Drug Metab Dispos 2001;29:1325-31.

8. Sun L, Lau CE. Simultaneous pharmacokinetic modeling of cocaine and its metabolites, norcocaine and benzoylecgonine, after intravenous and oral administration in rats. Drug Metab Dispos 2001;29:1183-9.

9. Shuster L, Garhart C, Powers J, Grunfeld Y, Kanel G. Hepatotoxicity of cocaine. In: Clouet D, Asghar K, Brown $\mathrm{R}$, editors. Mechanisms of cocaine abuse and toxicity. NIDA Research Monograph 88. Rockville (MD): National Institute on Drug Abuse; 1988. p. 250-75.

10. Powers JF, Shuster L. Subacute cocaine treatment changes expression of mouse liver cytochrome P450 isoforms. Pharmacology 1999;58:87-100.

11. Pasanen M, Pellinen P, Stenbäck F, Juvonen RO, Raunio H, Pelkonen $\mathrm{O}$. The role of CYP enzymes in cocaine-induced liver damage. Arch Toxicol 1995;69:287-90.

12. Vitcheva V, Mitcheva M. Changes in liver and brain cytochrome P450 after multiple administration of cocaine, alone and in combination with nifedipine. Arh Hig Rada Toksikol 2007;58:287-91.

13. Amacher DE, Schomaker SJ. Ethylmorphine N-demethylase activity as a marker for cytochrome P450 CYP 3A activity in rat hepatic microsomes. Toxicol Lett 1998;94:115-25.

14. Monostory K, Hazai E, Vereczkey L. Inhibition of cytochrome P450 enzymes participating in p-nitrophenol hydroxilation by drugs known as CYP 2E1 inhibitors. Chem Biol Interact 2004;147:331-40. 
15. Morishima HO, Abe Y, Matsuo M, Akiba K, Masaoko T, Cooper TB. Gender-related differences in cocaine toxicity in the rat. J Lab Clin Med 1993;122:157-63.

16. Whittington RA, Iso A, Khan K, Cooper TB, Morishima HO. Role of gender in the toxicity of norcocaine. J Lab Clin Med 1999;133:590-6.

17. Council of Europe. European Convention for the Protection of Vertebrate Animals used for Experimental and other Scientific Purposes. CETS No. 123, 1991. [displayed 30 May 2007] Available at http://conventions.coe.int/Treaty/ Commun/QueVoulezVous.asp?NT $=123 \& \mathrm{CM}=8 \& \mathrm{DF}=31 /$ 03/2011\&CL=ENG.

18. Antkiewicz-Michaluk L, Románska I, Vetulani J. $\mathrm{Ca}^{2+}$ channel blockade prevents lysergic acid diethylamideinduced changes in dopamine and serotonin metabolism. Eur J Pharmacol 1997;332:9-14.

19. Itzhak Y, Ali SF, Martin JL, Black MD, Huang PL. Resistance of neuronal nitric oxide synthase-deficient mice to cocaineinduced locomotor sensitization. Psychopharmacol 1998;140:378-86.

20. Knowles RG, Moncada S. Nitric oxide synthases in mammals. Biochem J 1994;298:249-58.

21. Lowry OH, Rosebrough NJ, Farr AL, Randall RJ. Protein measurement with the Folin phenol reagent. J Biol Chem 1951;193:265-75.

22. Guengerich FP. Microsomal enzymes involved in toxicology. Analysis and separation. In: Heis AW editor. Principals and methods of toxicology. New York (NY): Raven Press; 1987. p. 609-34.

23. Nash T. The colorimetric estimation of formaldehyde by means of the Hantzsch reaction. Biochem J 1953;55:41621.

24. Mazel P. Experiments illustrating drug metabolism in vitro - determination of microsomal anyline hydroxilase. In: La Du BN, Mandel HG, Way EL, editors. Fundamentals of drug metabolism and drug disposition. Wilkins, Baltimore; 1971. p. 546.

25. Omura T, Sato R. The carbon monoxide-binding pigment of liver microsomes. J Biol Chem 1964;239:2370-85.

26. Bump EA, Taylor YC, Brown MJ. Role of glutathione in the hypoxic cell cytotoxicity of misonidazole. Cancer Res 1983;43:997-1002.
27. Bashkatova V, Meunier J, Vanin A, Maurice T. Nitric oxide and oxidative stress in the brain of rats exposed in utero to cocaine. Ann NY Acad Sci 2006;1074:632-42.

28. Vetulani J. Drug addiction. Part III. Pharmacotherapy of addiction. Pol J Pharmacol 2001;53:415-35.

29. Nasif FJ, Hu XT, White FJ. Repeated cocaine administration increases voltage-sensitive calcium currents in response to membrane depolarization in medial prefrontal cortex pyramidal neurons. J Neurosci 2005;25:3674-9.

30. Konno Y, Sekimoto M, Nemoto K, Degawa M. Sex difference in induction of hepatic CYP2B and CYP3A subfamily enzymes bynicardipine and nifedipine in rats. Toxicol Appl Pharmacol 2004;196:20-8.

31. Cui X, Thomas A, Han Y, Palamanda J, Montgomery D, White RE, Morrison RA, Cheng KC. Quantitative PCR assay for cytochromes $\mathrm{P} 450 \mathrm{2B}$ and $3 \mathrm{~A}$ induction in rat precisioncut liver slices: correlation study with induction in vivo. $\mathrm{J}$ Pharmacol Toxicol Methods 2005;52:234-43.

32. Iwamoto IM, Moore CM, Fujiwara N, Christ MJ, Gries DM, Nakamura KT. m-hydroxy benzoylecgonine recovery in fetal guinea pigs. Drug Metab Dispos 2000;28:335-8.

33. Ladona MG, Gonzalez mL, Rane A, Peter RM, de la Torre R. Cocaine metabolism in human fetal and adult liver microsomes is related to cytochrome P450 3A expression. Life Sci 2000;68:431-43.

34. Arinc E, Bozcaarmutlu A. Catalyzation of cocaine Ndemethylation by cytochromes P4502B, P4503A, and $\mathrm{P} 4502 \mathrm{D}$ in fish liver. J Biochem Mol Toxicol 2003;17:16976.

35. Yu RCT, Lee TC, Wang TC, Li JH. Genetic toxicity of cocaine. Carcinogenesis 1999;20:1193-9.

36. Mazumder PK, Suqendran K, Vijayaraghavan R. Protective efficacy of calcium channel blockers in sulphur mustard poisoning. Biomed Environ Sci 1978;11:363-9.

37. Rofael HZ, Abdel-Rahman MS. The role of ketamine on plasma cocaine pharmacokinetics in rat. Toxicol Let 2002;129:167-76.

38. Nayak PK, Misra AL, Mulé SJ. Physiological disposition and biotransformation of $(3 \mathrm{H})$ cocaine in acutely and chronically treated rats. Pharmacol Exp Ther 1976; 196:55669. 


\section{Sažetak}

\section{NIFEDIPIN UBLAŽAVA DJELOVANJE KOKAINA NA ENZIMSKU AKTIVNOST U MOZGU I JETRI TE SMANJUJE NJEGOVO IZLUČIVANJE PUTEM MOKRAĆE}

Cilj je ovoga istraživanja bio utvrditi kako nifedipin ublažava djelovanje kokaina na enzimsku aktivnost u mozgu i jetri Wistar štakora te utječe li na njegovo izlučivanje putem mokraće. Mužjaci su podijeljeni u četiri skupine po šest jedinki: kontrolnu skupinu, nifedipinsku skupinu koja je pet dana intraperitonealno primala nifedipin u dozi od $5 \mathrm{mg} \mathrm{kg}^{-1}$; skupinu koja je pet dana primala kokain u dozi od $15 \mathrm{mg} \mathrm{kg}^{-1} \mathrm{na}$ dan te skupinu koja je zajedno primala nifedipin i kokain u odgovarajućim dozama.

Dvadeset i četiri sata nakon posljednje doze izmjerena je enzimska aktivnost sintaze dušičnoga oksida (nNOS) u mozgu, razina citokroma P450 te aktivnosti enzima etilmorfin-N-demetilaze i anilinhidroksilaze u jetri štakora.

Uzorci mokraće prikupljeni su 24 sata nakon posljednje doze kokaina odnosno kombinacije nifedipina i kokaina. Koncentracija kokaina u mokraći izmjerena je s pomoću vezanog sustava plinske kromatografije i spektrometrije masa.

Kokain je povećao aktivnost nNOS-a u mozgu za $55 \%(\mathrm{p}<0,05)$ u odnosu na kontrolnu skupinu, što upućuje na stvaranje tolerancije i ovisnosti. U kombiniranoj skupini nifedipin je značajno smanjio aktivnost nNOS-a u odnosu na skupinu koja je primila samo kokain.

Kokain je značajno snizio, a nifedipin značajno povisio razinu citokroma P450 u jetri te aktivnost etilmorfin$\mathrm{N}$-demetilaze i anilinhidroksilaze u odnosu na kontrolnu skupinu. U kombiniranoj skupini nifedipin je uspješno ublažio djelovanje kokaina na aktivnost spomenutih enzima.

Izlučivanje kokaina putem mokraće u kombiniranoj skupini bilo je značajno manje (35 \%) nego u skupini koja je primala samo kokain.

Ovi rezultati potvrđuju da nifedipin štiti od djelovanja kokaina i stvaranja ovisnosti, najvjerojatnije zbog interakcija u metabolizmu dvaju spojeva.

KLJUČNE RIJEČI: anilinhidroksilaza, citokrom P450, etilmorfin-N-demetilaza, GSH, nNOS

\section{CORRESPONDING AUTHOR:}

Vessela Vitcheva

Department of Pharmacology, Pharmacotherapy

and Toxicology

Faculty of Pharmacy, Medical University Sofia

Dunav str. 2, 1000 Sofia, Bulgaria

E-mail:vesselavitcheva@yahoo.com 